\title{
The Strengths and Weaknesses of Cooperative Learning and Problem- based Learning in EFL Writing Class: Teachers and Students' Perspectives
}

\author{
M. Ali Ghufron \\ English Education Department of IKIP PGRI Bojonegoro, East Java, Indonesia, \\ ali.ghufron@ikippgribojonegoro.ac.id \&alghufron.87@gmail.com
}

\section{Siti Ermawati}

English Education Department of IKIP PGRI Bojonegoro, East Java, Indonesia, ermawati.saja2016@gmail.com

\begin{abstract}
This study was aimed at evaluating the strengths and weaknesses of cooperative learning and problem-based learning in EFL writing classes. This study employed a case study method. The respondents of the research were 2 EFL writing teachers and 60 students who took EFL writing course in English Education Department of a private university in East Java, Indonesia. The respondents were chosen based on purposive sampling technique. The data was gained through questionnaires, indepth interview, and observation. After analyzing the data descriptively, the results show that raising student' self-confidence and motivation, reducing students' nervousness, raising students' responsibility in learning, and making the students easier to learn are the strengths of Cooperative Learning (CL). On the other hand, the weaknesses of CL are that it needs much more time to implement, it needs active participation from both teachers and students, it is difficult to manage, and it needs more preparation. While in Problem-based Learning (PBL), problem solving skills, self-directed learning skills, reducing students' nervousness, raising student' self-confidence and motivation, raising students' responsibility in learning, easily sharing and exchanging ideas among students, making the students more active in learning, making the students explore many learning sources to solve the problems, and making the students have positive attitude to learning were classified into the strengths of PBL.
\end{abstract}

Keywords: cooperative learning, problem-based learning, EFL writing, teachers' perspectives, students' perspectives

\section{INTRODUCTION}

Teaching EFL writing in Indonesia is very challenging (Ariyanti, 2016). It needs to implement innovative teaching and learning techniques. Besides, the technique should

Citation: Ghufron, M. A., \& Ermawati, S. (2018). The Strengths and Weaknesses of Cooperative Learning and Problem-based Learning in EFL Writing Class: Teachers and Students' Perspectives. International Journal of Instruction, 11(4), 657-672. https://doi.org/10.12973/iji.2018.11441a 
not only attractive and joyful but also promote other aspects which can affect students' EFL writing skill, such as creativity, apprehension, anxiety (Ghufron \& Hawa, 2015). Writing is one of the four major language skills and is very urgent in language classes. It is a necessity for EFL learners to write in English for occupational and academic purposes. Rivers (1981) states that writing is the most common way of examining the students' competence in the target language. Writing is defined as a means to reformulate and record knowledge as well as develop ideas (Hadley, 2003). Writing is considered as an important tool for expressing creativity and personal discovery.

Dealing with the learning model that could be implemented in EFL writing classes, there are some learning models which are joyful and attractive to teach EFL writing, such as cooperative learning and problem-based learning. Cooperative learning has been researched for over 50 years and connected positively to students' performance (Adams, 2013). Cooperative learning is a learning model in which the students are working together in small groups to help each other to complete a common task (Roger \& Johnson, 1994; Siegel, 2005; Slavin, 1983). Further, Roger \& Johnson (1994), argue that in a cooperative learning situation, interaction among students is characterized by positive goal interdependence with individual accountability. Positive goal interdependence requires acceptance by a group that they "sink or swim together". As teachers incorporate cooperative learning strategies into the classroom, not only characteristics such as positive interdependence and individual accountability are stressed, but also face-to-face interaction, social skills, and group processing must be taken into account (Adams, 2013; Cole, 2012; Yumi \& Erina, 2015). Hendrix (1999) elaborates that positive interdependence is a condition in which the students are linked together with other students in such a way that one cannot succeed unless the group members also succeed. Face-to-face interaction is the situation in which the students will explain each other the problems and individual accountability is a requirement for students to complete their share of the work. Individual accountability may become problematic for educators when the students do not participate actively in the cooperative learning strategy. Social skills are also needed to achieve mutual goals, therefore, the students must know and trust each other, communicate effectively, and support and encourage each other (Adams, 2013; Hendrix, 1999).

The next learning model is problem-based learning (PBL). Originated in the 1960s at McMaster University Medical School, Canada, PBL is a collaborative, constructivist, and contextualized learning and teaching approach that uses real-life problems to initiate, motivate and focus knowledge construction (Ribeiro, 2011). Although its origin is in the teaching of medical and health sciences, PBL rapidly expanded to the teaching of other disciplines, such as engineering (Woods, Felder, Rugarcia, \& Stice, 2000; Woods, 1996), education (Alwi, Yusof, Hashim, \& Zainon, 2012), and also EFL learning (Ng Chin Leong, 2009). It is commonly agreed that PBL starts with an unstructured problem that has more than one answer. Students have to collaboratively learn together through the PBL cycle (Mohd-yusof, Helmi, Jamaludin, \& Harun, 2011; Yusof, Hassan, Jamaludin, \& Harun, 2012). The unstructured problems are used as the starting point of learning, creating deep interests among students to learn new knowledge and integrate existing ones, and forcing them to think critically and 
creatively to solve the problem (Boud \& Feletti, 1997; Tan, 2003; Woods et al., 2000; Woods, 1996).

\section{Cooperative Learning in EFL writing classes}

There are some studies that revealed the effectiveness of cooperative learning in EFL classes. Some of the studies indicated that cooperative learning could help students develop their English language skills, including writing skills (Atkinson, 2003; Chen, 2004; Cole, 2012; Elola \& Oskoz, 2010; Mahmoud, 2014; Wong, Chin, Chen, \& Gao, 2009). Those studies enabled the researchers to build the theoretical background about the implementation of the cooperative learning to enhance students' EFL writing skills. However, these studies have been mostly limited to writing in the secondary school setting within ESL writing classrooms, except Mahmoud's (2014) study. Some of the previous studies focused on the use of cooperative learning within tertiary writing classrooms, but it still needs more insights to show how cooperative learning could be implemented in specific academic settings respectively to the concerns highlighted in the previous studies. Although empirical evidence advocated the effectiveness of the use of cooperative learning in various subject areas and different age groups, there is still less evidence regarding the strengths and weaknesses of CL in its implementation in EFL writing classes.

\section{Problem-based Learning in EFL writing classes}

The student-centered pedagogical approach in which students learn about a subject through the experience of solving an open-ended problem found in trigger material is called problem-based learning. There must be a contextual problem which can stimulate the students to learn the topic with high order thinking skill (HOTS). There are a number of studies in PBL which have been done by many researchers, and one of them is Iswandari (2017). She examines the effect of environmental problem-based learning (PBL) on the environment-related vocabulary mastery and writing ability of Indonesian EFL students. Her study revealed that the students who were taught by using environmental PBL improved their environment-related vocabulary mastery and their writing ability significantly. Another study was also conducted by (Lin, 2012, 2015). Her studies revealed that through PBL approach, students yielded a significant advancement in the vocabulary test and a higher proportion of vocabulary used in which it affects on students' writing skill. To sum up, PBL could help the students in preparing good essays (Dastgeer, 2015; Kusmawati \& Purwati, 2015; Lin, 2012, 2015). However, so far there has been no study focused on evaluating the strengths and weaknesses of PBL when it is implemented in EFL writing classes.

\section{Research Objective}

Based on the explanation above, it is mentioned that the objective of this study was to evaluate the strengths and weaknesses of cooperative learning and problem-based learning in EFL writing classes. 


\section{METHOD}

\section{Research Design}

The qualitative research based on the case study design is an appropriate way to provide a "holistic description and analysis of a single instance, phenomenon, or social unit" (Merriam, 1998). Further, Yin (2003) elaborates that "case study is used in many situations to contribute to our knowledge of individual, group, organizational, social, political, and related phenomena. Based on the characteristics listed above, case study design was used in this study in order to provide a rich and detailed information dealing with the implementation of CL and PBL and their strengths and weaknesses in EFL writing classes based on teachers and students' perceptions.

\section{Participants of the Study}

This study was conducted in English Education Department, Faculty of Languages and Arts Education, Institute of Teacher Training \& Education of PGRI Bojonegoro, East Java, Indonesia at the odd semester in the academic year of 2017/2018. There were 11 EFL teachers and 120 students who took EFL writing course in that department and in that academic year. The participants in this study were chosen by using two types of purposeful sampling technique i.e. criterion and intensity sampling, in order to purposefully selects participants to maximize information. According to Patton (2002), criterion sampling involves the cases that meet some predetermined criterion of importance. The criterion sampling was used to select teachers that meet some criteria such as teachers' experience in conducting CL and PBL tutorials in EFL writing classes and teachers should be willing to take part in the study. Finally, two EFL teachers were selected.

In selecting the students, the researchers used intensity sampling which involves selecting cases that are information-rich manifesting the phenomena of interest intensely but not extremely (Patton, 2002). There were 10 students from each grade level who have high, low, and medium cumulative grade points and selected to participate in this study. Therefore, there were 30 students from each cooperative learning and problembased learning class. This selection category was applied since the researchers wanted to get more comprehensive information dealing with the strengths and weaknesses of CL and PBL from different points of view.

\section{Context}

In this English Education Department, CL and PBL have been commonly used in teaching and learning process, including EFL writing classes. Teachers in this department have implemented various techniques which belong to $\mathrm{CL}$, such as jigsaw, magic sentence, dyadic essay, and so forth. Dealing with PBL, a module has been made consisting of PBL tutorial sessions, presentations, laboratories, scientific consultation, and module discussion hours. PBL sessions take 100 minutes for each face-to-face meeting providing a learning environment where students attempt to define and then solve a real-life problem introduced with a motivating scenario. The role of the teachers in $\mathrm{CL}$ and PBL is as facilitators. 


\section{Data Collection Technique}

\section{Observation}

The observation was done during teaching and learning process of EFL writing in order to evaluate the current practices applied in writing classes. Some documents related to teaching and learning process, e.g. syllabus and lesson plan, were also analyzed for further evaluation. The data from observations were collected through non-participant observation. An observation checklist was also developed as a guide in order to make a better report of how frequent some CL and PBL characteristics occurred during teaching and learning process. During observations, the researchers also took notes related to the participants' actions and the process of CL and PBL, and then, they filled observation checklist and added some comments.

\section{In-depth Interviews}

In-depth interview was also conducted with the teachers and some students who were chosen purposively. Data from the interviews were recorded and collected. The responses from interview sessions were transcribed for analysis by using the coding processes. Coding process was used as it is more practical for the researchers to classify the data into specific categories and terms, related to the study. The first phase is the open coding where the researchers had to revise the responses frequently to understand the idea that is related to the study. The second step is axial coding where the researchers try to relate the first step to the second step by categorizing them into different terms and categories. The third phase, also the last, is selective coding where the researchers will select and also identify the primary categories, relating them back to the aim of the study. The coding is then manually typed into Microsoft Words for the transcribing of data.

\section{Questionnaires}

At the end of learning, the students were given a questionnaire in order to evaluate the implementation of CL and PBL. The questionnaire uses the Likert scale for scoring. The students should mark the numbers between 1 to 5 ( $1=$ very poor, $5=$ excellent $)$. The results of the questionnaire were, then, compared with the results of qualitative data. According to Patton (2002), methods of triangulation often involves comparing and integrating data collected through some kind of qualitative methods with data collected through some kind of quantitative methods. Therefore, in order to test the consistency of the data obtained qualitatively from observations and interviews, some questionnaires were selected according to their relevance to the research questions (see Creswell \& Miller, 2000; Creswell, 2012). The questionnaires were validated by expert judgments.

\section{Data Analysis}

After the data was obtained, it was analyzed by examining the "bottom-up" approach. The researchers first collect data and then prepare it for data analysis. This analysis initially consists of developing a general sense of the data, and then coding description and themes about the central phenomenon (Creswell, 2012). In this study, coding schemes were used to gain a more detailed perspective about what was occurring based on the purpose of the study. These coding schemes helped to analyze the transcripts of 
the participants. Besides, descriptive statistics were also used to analyze quantitative data gained from the questionnaires.

\section{FINDINGS AND DISCUSSION}

\section{The Implementation Process of Cooperative Learning and Problem-based Learning in EFL Class}

Based on the results of class observation, the researchers found some important things that dealt with the implementation of cooperative learning and problem-based learning in EFL writing classes. The researchers conducted observation for two weeks in two EFL writing classes, one class implemented PBL and another Cooperative learning. The summary of the observation findings are presented in table 1 and 2:

Table 1

The implementation process of Cooperative Learning in EFL writing classes

\begin{tabular}{ll}
\hline Teacher & Explaining the learning outcomes \\
Giving questions to the students dealing with the topic to bring the students to the topic \\
Explaining the topic \\
Asking the students to make a small group (two or three students in each group) \\
Explaining the material/topic \\
Asking the students to discuss the topic in the group and to write the points (the \\
students may ask the difficult point to the teacher) \\
Asking the students to write a certain topic based on their discussion with their \\
teammates \\
$\begin{array}{l}\text { Making a small group based on the teacher's instruction } \\
\text { Discussing the topic with their teammates } \\
\text { Making some notes of important points from the discussion } \\
\text { Asking some difficult points to the teacher } \\
\text { Writing an essay based on the topic given individually } \\
\text { Exchanging the draft of the essay with their teammates' and correct it } \\
\text { The students, individually, revise their exchanged draft of the essay }\end{array}$ \\
The teacher checked students' participation during teaching and learning process by \\
making some notes \\
The teacher asked the students to submit the revised draft of the essay \\
The teacher gave feedback to students' draft of the essay but it was not finished
\end{tabular}

As the results of the fieldnotes during the implementation of CL, it was revealed that: 1) Students actively participated in the learning process, 2) Students were motivated to learn when they were in the group, 3) Social interaction reduced students' nervousness during the learning process, 4) Students tried to be responsible for their own task when they were in the group, 5) The teacher seemed to get difficulties in organizing the class, 6) The grouping made by the teacher was imbalance (the teacher should determine some aspects of the grouping, such as gender and students' capabilities), 7) The time was very limited if Cooperative Learning was implemented in only one meeting, and 8) The assessment given by the teacher was not complete (due to the limited time).

The results of observation during the implementation of PBL in EFL writing classes is 
presented in table 2.

Table 2

The implementation process of PBL in EFL writing classes

\begin{tabular}{ll}
\hline & \multicolumn{1}{c}{ Activities and notes } \\
\hline Teacher & Giving and explaining the problem (based on contextual case/recent issue) \\
- Giving questions to the students dealing with the problem in order to check \\
students' understanding of the problem \\
- Encouraging the students to solve the problems cooperatively with their mates \\
- Asking the students to go outside the class (if needed) to explore possibilities and to \\
solve the problems \\
- Guiding the students in conducting research through reading materials needed from \\
the internet \\
- Reading and understanding the problem given by the teacher \\
- Identifying the main problems through small discussion \\
- Brainstorming the problem by linking their previous knowledge with the problem \\
- Some students were going out of the class to interview some respondents dealing \\
- with the issue/problem \\
- Sharing with their teammates and writing the results of the discussion \\
- Writing the rough draft of essay individually \\
- Exchanging the draft of the essay with their teammates' and correct it \\
- The tudents, individually, revise their exchanged draft of the essay \\
- Thecked students' participation during teaching and learning process by \\
- The teacher checked students' understanding of the problem by asking the results of \\
the students' discussion with their teammates \\
- The teacher asked the students to submit the revised draft of the essay
\end{tabular}

As the results of fieldnotes during the implementation of PBL, it was revealed that: 1) Students actively participated in the learning process, 2) Students were motivated to learn when they were in the group, 3) Students tried to solve the problem given by exploring all learning resources, 4) Students have positive attitudes towards the learning process, 5) Social interaction reduced students' nervousness during the learning process, 6) Students tried to be responsible for their own task when they were in the group, 7) Students seemed confused about what to do with the problem, 8) The teacher should explain more clearly what the students should do, 9) The teacher seemed to get difficulties in organizing the class, 10) The grouping made by the teacher was imbalance (the teacher should determine some aspects of the grouping, such as gender and students' capabilities), 11) The time was very limited if PBL was implemented in only one meeting, 12) The assessment given by the teacher was not complete (due to the limited time), and 13) The implementation of PBL was not suitable for the lesson plan made.

The strengths and weaknesses of Cooperative Learning and Problem-based Learning in EFL writing class

The Strengths of CL and PBL in EFL Writing Classes

To evaluate the strengths of CL and PBL during its implementation in EFL writing classes, the data from in-depth interviews with teachers and students and questionnaires 
distributed to teachers and students were gathered. The results of the in-depth interview with teachers are as follows.

The following are the transcript of the interview:

Question : If you ever implemented cooperative learning and problem-based learning in your EFL writing classes, would you please to tell us the strengths and weaknesses of the two learning models based on your experience?

Teacher 1 : Umm.. ya, to me, CL and PBL are very useful learning models to be implemented in EFL learning. CL can make students active, more motivated, more responsible for their work, and students can also share their ideas with their teammates.

About PBL, I think it is very challenging both for students and teacher. It makes the students more active, more motivated, have the high responsibility to their works, able to share and exchange ideas to their mates, and of course, it makes them use all their skills to solve the problem given.

Teacher 2 : To me, CL can make the students more motivated since they work in a group, can raise students' self-confidence, and can make the students easier to understand the lesson since they can discuss with their partners.

PBL... ummm... PBL makes the students more motivated, have high selfconfidence, eager for the lesson by exploring all learning resources to solve the problem, and have a positive attitude to learning.

From the interview with the teachers above, it can be inferred that raising student' selfconfidence and motivation, reducing students' nervousness, raising students' responsibility in learning, and making the students easier to learn are the strengths of CL. Meanwhile in PBL, problem solving skills, self-directed learning skills, reducing students' nervousness, raising student' self-confidence and motivation, raising students' responsibility in learning, easily sharing and exchanging ideas among students, making the students more active in learning, making the students explore many learning sources to solve the problems, and making the students have positive attitude towards learning are classified into the strengths of PBL.

Besides an interview with the teacher, an interview with the students was also conducted to reveal the students' perception of the strengths of CL and PBL in EFL writing classes. The findings from the interview with the students reveal that the students mostly agreed that the implementation of $\mathrm{CL}$ and PBL gave them many positive impacts. The following are the students' opinion:

Question : What do you think about the implementation of CL and PBL in EFL writing classes? Do they give benefit to you?

Student A Sure... I think when we work on CL, our self-confidence and motivation are raising. Besides, when we have to make a presentation, it can reduce our nervousness. Working in a group also make us easily understand the lesson, and of course, all of us will be responsible for learning.

About PBL, it as a very challenging to me. Because we were faced with the real problem. Therefore, before writing, we have to conduct such kind of research to explore and solve the problem. It also gives many positive impacts on us. It can raise our motivation and self-confidence, it can train us how to solve a problem, it can reduce our nervousness, make us more responsible to learning, make us love to learning, and many more. 
The data gained from the interviews above were also triangulated with the data gained from the questionnaires. Further, the results of the questionnaires distributed to teachers are as follows.

Table 3

A part of the questionnaire for teachers

\begin{tabular}{lll}
\hline No. Questions & \multicolumn{1}{c}{ Answers } \\
\hline 11. & Mention the strengths \\
and weaknesses of & Teacher 1: \\
cooperative learning & Strengths: \\
based on your own & Through CL students are more motivated \\
experience! & Through CL students are trained to have a high \\
& responsibility for learning \\
& Through CL, students will learn how to share and \\
exchange their ideas with others & Teacher 2: \\
& Strengths: \\
& It makes the students more motivated \\
& It makes students have higher self-confidence \\
& It makes the students easier to understand the lesson \\
\hline Mention the strengths & Teacher 1: \\
and weaknesses of & Strengths: \\
problem-based-learning & Through PBL, students are more motivated \\
based on your own & Through PBL, students are trained to have a high \\
experience! & responsibility for learning \\
& Through PBL, students will learn how to share and \\
& exchange their ideas with others \\
& Through PBL, students will actively participate in learning \\
& Through PBL, students will explore their skills to solve \\
& the problem \\
& Teacher 2: \\
& Strengths: \\
& It makes the students more motivated \\
& It makes students have higher self-confidence \\
& It makes the students eager for the lesson by exploring all \\
learning resources to solve the problem \\
It makes the students have a positive attitude to learning \\
\hline
\end{tabular}

Based on the results of the questionnaires which were distributed to the students, it was revealed that the strengths of CL are that it could promote students self-confidence and motivation, it can reduce students' nervousness during the learning process, raise students' responsibility in learning, and make the students easily learn the material through sharing of ideas. Meanwhile, the strengths of PBL are that it could promote students' self-confidence and motivation, it can reduce students' nervousness during the learning process, raise students' responsibility in learning, make the students easily learn the material through sharing of ideas, promote problem-solving skills, promote selfdirected learning, promote active learning, make the students explore many learning resources, and make the students have a positive attitude towards learning. The details are presented in the following figure: 


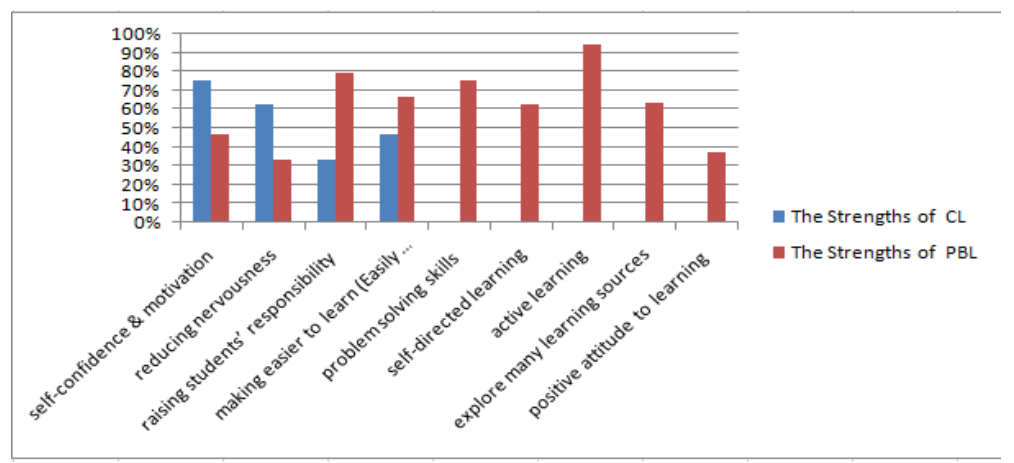

Figure 1

The Strengths of CL and PBL According to the Students

The Weaknesses of CL and PBL in EFL writing classes

Similarly, to evaluate the weaknesses of CL and PBL during its implementation in EFL writing classes, the data from in-depth interviews with both teachers and students and the questionnaires distributed to both teachers and students were gathered.

Based on the results of interviews, it was revealed that the most common problem during the implementation of $\mathrm{CL}$ is that it needs much more time to be implemented, active participation from both teachers and students, more preparation, especially in grouping (the criteria for choosing the member of group), and it is difficult to manage.

Almost similarly, the implementation of PBL also faced some problems. It was revealed it difficult to implement the PBL; it needs much more time, more preparation, good management, and it is confusing for some students.

The followings are the teachers' opinions dealing with the weaknesses and problems during the implementation of CL and PBL in EFL writing classes:

Question : If you ever implemented cooperative learning and problem-based learning in your EFL writing classes, would you please to tell us the strengths and weaknesses of the two learning models based on your experience?

Teacher $1 \quad$ : ............. The weaknesses of CL, umm... I think it needs much more time to implement, teachers also must be active, I think; and sometimes, it is difficult to manage the students. (chuckled)

Unfortunately, PBL also needs much more time, very difficult to implement, and sometimes it is confusing.. (Laughing).

Teacher 2 : ........... The weaknesses of $\mathrm{CL}$ are: it needs more time, needs more preparation especially in making group, and needs good management from the teacher.

............. For the weaknesses of PBL, it needs more time, more preparation, good management, sometimes, it is also confusing.. (Chuckled), and difficult to implement.

Further, the students have also stated that the implementation of CL and PBL has some weaknesses. The following is the results of the interview conducted with the students. 
Question : What do you think about the implementation of CL and PBL in EFL writing classes? Do they give benefit to you?

Student C $\quad$....... But, CL sometimes makes us confused. Besides, the problem also arouses when all members of the team did not understand comprehensively to the lesson. Therefore, none of them could do the writing.

...... ya, PBL sometimes also makes us confused what to do. It happened when the teacher's instruction is not clear enough. Therefore, we think that PBL is quite hard to be implemented. (chuckled..)

The data obtained from the interview above were also triangulated with the data obtained from the questionnaires. The results of the questionnaires dealing with the weaknesses of PBL are as follows.

Table 4

A part of the questionnaire for teachers

\begin{tabular}{lll}
\hline No. & Questions & Teacher 1: \\
\hline 11. & Mention the strengths & Answers \\
and weaknesses of & Weaknesses: \\
cooperative learning & CL needs much more time to implement \\
based on your own & CL needs active participation not only from students but \\
experience! & also from teachers \\
& CL is difficult to manage \\
& Teacher 2: \\
& Weaknesses: \\
& It needs more time \\
& It needs more preparation including in making a group \\
& It needs good management \\
\hline Mention the strengths & Teacher 1: \\
and weaknesses of & Weaknesses: \\
problem-based-learning & PBL is difficult to implement \\
based on your own & PBL needs much more time to implement \\
experience! & PBL sometimes makes the students and teacher confused \\
& Teacher 2: \\
& Weaknesses: \\
& It needs more time \\
& It needs more preparation including in making a group \\
& It needs good management \\
& Sometimes, it is confusing \\
& It is difficult to be implemented
\end{tabular}

Further, based on the results of the questionnaires which were distributed to the students, it was revealed that the weaknesses of CL are that sometimes it is confusing for the students, and the group made by the teacher is imbalance (e.g. some groups have the skillful members, and the other groups have less skillful members) since the grouping technique is through lottery. Meanwhile, the weaknesses of $\mathrm{PBl}$ are that it is confusing for the students, the group made by the teacher is imbalance (e.g. some groups have the skillful members, and the other groups have less skillful members) since the grouping technique is through lottery, the instruction given are sometimes unclear for the students, and it is hard to be implemented. The details are presented in the following figure: 


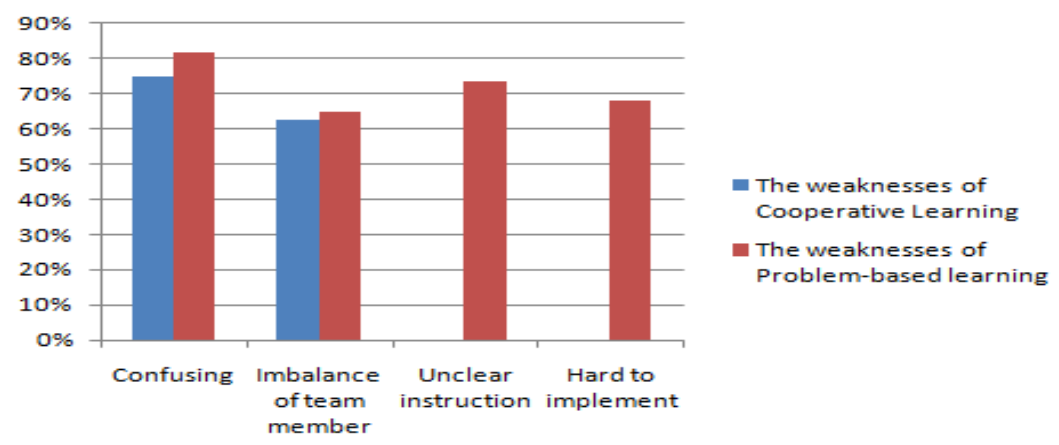

Figure 2

The Weaknesses of CL and PBL According to the Students

\section{DISCUSSION}

\section{The Strengths and Weaknesses of CL in EFL writing class}

Based on the findings, it is mentioned that one of the strengths of CL in EFL writing classes is that it can raise students self-confidence and motivation. It is in line with Yumi \& Erina's (2015) study which reveals that incorporating cooperative learning into a writing activity could promote students' fluency and gain their confidence toward writing, and build up their motivation. Other strengths of CL is that social interaction reduces students' nervousness during the learning process, it can raise students' responsibility in learning, and it can make the students easier to learn through sharing of ideas. Those are compatible with Cloud's (2014) research which reveals that in CL social interaction between members of a given group helps dissolve nervousness and insecurity. In his research, he also states that CL can train leadership skills, such as to manage many different tasks at once and keep everyone on track. CL helps to develop these skills because each person is held accountable by the other. Further, he also argues that CL makes the students easily express and share their ideas with their mates.

Dealing with the weaknesses of CL, it is elaborated in the findings that CL also has some weaknesses during its implementation in EFL writing classes. The weaknesses are the needs of much time for preparation before implementation. Cloud (2014) divides the CL into three types, i.e. formal CL, informal CL, and CL base group. Formal CL is effective for long period of learning, such as writing a paper or essay. Therefore, if CL is implemented in EFL writing classes, of course, it needs much more time since it belongs to formal CL. In informal CL, the groups are made in class and can last from a few minutes to one class period. While in CL base groups, the groups are created early on in a group of students to help foster relationships over time and can last for years. The other weaknesses are that it is difficult to manage and needs active participation from both teacher and students. Adams (2013) argues that CL is difficult to manage since, in its implementation, the teacher must be able to incorporate the foundations of CL such as positive interdependence, face-to-face interaction, individual accountability, group processing, and social skills. Therefore, CL is a bit difficult to manage and active participation from all parties is needed. 


\section{The Strengths and Weaknesses of PBL in EFL writing class}

Based on the findings, it is mentioned that problem-solving skills, self-directed learning skills, reducing students' nervousness, raising student' self-confidence and motivation, raising students' responsibility in learning, easily sharing and exchanging ideas among students, making the students more active in learning, making the students explore many learning sources to solve the problems, and making the students have positive attitude to learning are the strengths of PBL in EFL writing classes. Ateş \& Eryılmaz (2010) confirmed that implementing PBL is a viable and feasible way to promote students' problem-solving skills and self-directed learning skills. Futher, Borhan (2012) asserted the students who experienced in PBL could foster their self-confidence and motivation, reduce their nervousness during the learning process, have a positive attitude to learning, and raise their responsibility in learning as they work in a team. He also elaborated that team working could make the students easily share and exchange the ideas and more active in learning. Moreover, $\mathrm{Ng}$ Chin Leong (2009) states that one of the benefits of PBL is that students can adopt a creative stance to solve the problem including exploring many learning resources.

Meanwhile, the findings also reveal that PBL in EFL writing classes has some weaknesses. The weaknesses are that it is difficult to implement, it needs much more time, more preparation, good management, and it is confusing for some students. Those are compatible with $\mathrm{Ng}$ Chin Leong's (2009) study which reveals that the weaknesses of PBL are that it is confusing for some students at first; some students are hesitant to discuss their thoughts about the problem, and it is difficult for teachers to arrange an open-ended problem for the learning process. Further, Ribeiro (2011) asserted that the implementation of PBL is difficult, it needs more time for preparation, and it is difficult to manage. Those are due to PBL needs an arrangement of an open-ended problem before its implementation and the obstacles found during its implementation, such as the losses perceived by the teacher, e.g., reduced control over content coverage and teaching-related workload.

\section{CONCLUSION AND IMPLICATION}

Based on the teachers' experience in implementing CL and PBL, it was revealed that both of the learning models have their own strengths and weaknesses. CL is good in making the students actively participate in the learning process; raising students' motivation, reducing students' nervousness, making the students responsible on their task, making the students easily express and share their ideas, building self-confidence, and making them easier to understand the lesson. However, it needs much more time to implement, it needs active participation from both teacher and students, it is difficult to manage, and it needs more preparation. PBL also has its own strengths and weaknesses. PBL is good in reducing students' nervousness, motivating students, making the students responsible for learning, making the students learn how to share and exchange their ideas with others, making the students actively participate in learning, making the students explore their skills to solve the problem, raising the students' self-confidence, making the students eager to the lesson by exploring all learning resources to solve the problem, and making the students have positive attitude to learning. While the 
weaknesses of PBL are that it is difficult to implement, it needs much more time, more preparation, good management, and it is confusing for some students.

Those results should be taken into account by EFL writing teachers and students while preparing, implementing and evaluating CL and PBL in EFL writing classes and making necessary revisions to overcome those weaknesses and solve the problems. Besides, EFL writing teachers should be creative and innovative in implementing various pedagogical attempts since it can help students to promote their English skills (Rosyida \& Ghufron, 2018).

\section{ACKNOWLEDGMENT}

This research is partly funded by Indonesian Ministry of Research, Technology, and Higher Education on Penelitian Dosen Pemula (PDP) research scheme of the year 2018.

\section{REFERENCES}

Adams, A. R. (2013). Cooperative learning effects on the classroom. Michigan.

Alwi, S. R. W., Yusof, K. M., Hashim, H., \& Zainon, Z. (2012). Sustainability education for first year engineering students using cooperative problem based learning. In Procedia - Social and Behavioral Sciences (Vol. 56, pp. 52-58). https://doi.org/10.1016/j.sbspro.2012.09.631

Ariyanti. (2016). The teaching of EFL writing in Indonesia. Dinamika Ilmu, 16(2), 263277. https://doi.org/10.21093/di.v16i2.274

ATEŞ, Ö., \& ERYILMAZ, A. (2010). Strengths and weaknesses of problem-based learning in engineering education: Students' and tutors' perspectives. Buca Eğitim Fakültesi Dergisi, 28, 40-58.

Atkinson, D. (2003). L2 Writing in the post-process era: Introduction. Journal of Second Language Writing, 12, 3-15.

Borhan, M. T. (2012). Problem-based learning (PBL) in Malaysian higher education: A review of research on learners' experience and issues of implementations. ASEAN Journal of Engineering Education, 1(1), 48-53.

Boud, D., \& Feletti, G. (1997). Changing poblem based learning: In the challenge of problem-based learning. London, UK: Boud and Feletti Eds.

Chen, M. L. (2004). A study of the effects of cooperative learning strategies on student achievement in English as a Foreign Language in a Taiwan college. New York: ProQuest Information and Learning Company.

Cloud, T. (2014). Cooperative learning in the classroom. Journal on Best Teaching Practices, (June), 7-8.

Cole, K. S. (2012). Promoting cooperative learning in an expository writing course. Journal of International Education Research -Second Quarter, 8(2), 113-124.

Creswell, J. W. (2012). Educational research: Planning, conducting and evaluating 
quantitative and qualitative research (4th ed.). Boston: Pearson Education Inc.

Creswell, J. W., \& Miller, D. M. (2000). Determining validity in qualitative inquiry. Theory into Practice, 39(3), 124-130.

Dastgeer, D. M. (2015). Improving English writing skill: A case of problem-based learning. American Journal of Educational Research , 3(10), 1315-1319.

Elola, I., \& Oskoz, A. (2010). Collaborative writing: Fostering foreign language and writing conventions development. Language Learning \& Technology, 14(3), 51-71.

Ghufron, M. A., \& Hawa, M. (2015). The effect of collaborative writing technique in teaching argumentative essay writing viewed from the students ' creativity. LANGUAGE CIRCLE: Journal Lof Language and Literature, 10(1), 49-60.

Hadley, A. O. (2003). Teaching language in context (3rd Ed.). New York: Heinle \& Heinle Publication.

Hendrix, J. C. (1999). Connecting cooperative learning and social studies. The Clearing House, 57-63. Retrieved from http://ezpolson.nmu.edu:5749/ps/i.do?\&id=GALE|A55684628\&v=2.1\&u=lom_nmichu \&i $\mathrm{t}=\mathrm{r} \& \mathrm{p}+\mathrm{ITOF} \& \mathrm{sw}=\mathrm{w}$

Iswandari, D. C. (2017). Effect of environmental problem-based learning on the Indonesian EFL students' environment-related vocabulary mastery and writing ability. Theory and Practice in Language Studies, 7(8), 608-616.

Kusmawati, D. P., \& Purwati, O. (2015). The implementation of problem-based learning in teaching writing descriptive text to the eighth graders. Retain, 3(2), 1-7.

Lin, L. F. (2012). The application of the problem-based learning approach to a second language learning context. In Proceedings of edmedia: world conference on educational media and technology (pp. 2465-2470).

Lin, L. F. (2015). The impact of problem based learning on Chinese-speaking elementary school student's English vocabulary learning and use. System, 55, 30-42.

Mahmoud, M. M. A. (2014). The effectiveness of using the cooperative language learning approach to enhance EFL writing skills among Saudi university students. Journal of Language Teaching and Research, 5(3), 616-625. https://doi.org/10.4304/j1tr.5.3.616-625

Merriam, S. B. (1998). Qualitative research and case study applications in education. San Francisco: Jossey-Bass.

Mohd-yusof, K., Helmi, S. A., Jamaludin, M. Z., \& Harun, N. F. (2011). Cooperative problem-based learning (CPBL): A practical PBL model for a typical course. In International Conference EDUCON2011 (pp. 12-20).

$\mathrm{Ng}$ Chin Leong, P. (2009). The power of problem-based learning (PBL) in the EFL classroom. Polyglossia, 16(2), 41-48. 
Patton, M. Q. (2002). Qualitative research and evaluation methods (3rd ed.). Thousand Oaks, CA: Sage Publications.

Ribeiro, L. R. C. (2011). The pros and cons of problem-based learning from the teacher's standpoint. Journal of University Teaching \& Learning Practice Volume, 8(1).

Rivers, W. M. (1981). Teaching foreign language skills (2nd Ed.). Chicago: Library of Congress Cataloging in Publication Data.

Roger, T., \& Johnson, D. W. (1994). An overview of cooperative learning. In Creativity and Collaborative Learning (pp. 1-21).

Rosyida, F., \& Ghufron, M. A. (2018). Herringbone and tri focus steve snyder technique : The techniques for teaching reading comprehension viewed from students, reading habit. International Journal of Instruction, 11(3), 603-616. Retrieved from http://www.e-iji.net/dosyalar/iji_2018_3_41.pdf

Siegel, C. (2005). Implementing a research based model of cooperative learning. The Journal of Educational Research, 98(6), 1-15.

Slavin, R. E. (1983). An introduction to cooperative learning. New York: Longman.

Tan, O. S. (2003). Problem-based learning innovation: Using problems to power learning in the 21st Century. Singapore: Thomson Learning.

Wong, L.-H., Chin, C.-K., Chen, W., \& Gao, P. (2009). An innovative collaborative writing approach to improve Chinese as L2 pupils' linguistic skills. In Proceedings of International Conference on Computer-supported Collaborative Learning (pp. 651661). Rhodes Island, Greece.

Woods, D. R. (1996). Problem-based learning: Helping your students gain most from $P B L$ (3rd Ed.). Ontario: D. R. Woods Publishing.

Woods, D. R., Felder, R. M., Rugarcia, A., \& Stice, J. M. (2000). The future of engineering education: III. Developing critical skills. Chemical Engineering Education, 34(2), 108-117.

Yin, R. K. (2003). Case study research: Design and methods (3rd ed.). Thousand Oaks, CA: Sage Publications.

Yumi, F., \& Erina, S. (2015). Effects of cooperative learning on writing activity of English for special purposes in Japanese university students. Journal of Academic Society for Quality Life, 1(1), 32-39.

Yusof, K. M., Hassan, S. A. H. S., Jamaludin, M. Z., \& Harun, N. F. (2012). Cooperative Problem-based Learning (CPBL): Framework for integrating cooperative learning and problem-based learning. In Procedia - Social and Behavioral Sciences (Vol. 56, pp. 223-232). https://doi.org/10.1016/j.sbspro.2012.09.649 